\title{
Regenerasi Kalus Berfilamen Rumput Laut Kappaphycus alvarezii Pada berbagai Perbandingan Zat Pengatur Tumbuh Auksin (Indole Acetic Acid) dan Sitokinin (Kinetin, Zeatin)
}

\author{
Sri Redjeki Hesti Mulyaningrum ${ }^{1} *$, Andi Parenrengi ${ }^{2}$, Yenny Risjani ${ }^{1}$, Happy Nursyam ${ }^{1}$ \\ ${ }^{1}$ Fakultas Perikanan dan Kelautan, Universitas Brawijaya, Malang \\ ${ }^{2}$ Balai Riset Perikanan Budidaya Air Payau, Maros, Sulawesi Selatan
}

\begin{abstract}
Abstrak
Interaksi auksin-sitokinin dianggap penting untuk mengatur pertumbuhan dan perkembangan dalam jaringan tanaman. Penelitian ini bertujuan untuk menentukan komposisi auksin dan sitokinin yang tepat untuk regenerasi filamen kalus rumput laut $K$. alvarezii. Kultur filamen kalus dilakukan pada media cair dengan formulasi ZPT indole acetic acid (IAA) : kinetin : zeatin, dengan komposisi konsentrasi sebagai berikut : A (0,4:0:1) ppm; B (0,4:0,25:0,75) ppm; C (0,4:0,5:0,5) ppm; D (0,4:0,75:0,25) ppm; E (0,4:1:0) ppm; kontrol (tanpa ZPT). Penelitian menggunakan rancangan acak lengkap dengan pengulangan masing-masing perlakuan 3 kali. Parameter yang diamati adalah laju pertumbuhan harian, sintasan, kecepatan regenerasi, panjang tunas dan perkembangan morfologi. Hasil yang diperoleh menunjukkan bahwa formula ZPT terbaik adalah formula A dengan laju pertumbuhan harian 1,929\%/hari, sintasan $83,33 \%$, kecepatan regenerasi $41,67 \%$ dan rata-rata panjang tunas $44,59 \mu \mathrm{m}$. Tunas mulai terbentuk pada 15 hari masa kultur.
\end{abstract}

Kata kunci: formula zat pengatur tumbuh, auksin-sitokinin, K. alvarezii, mikropropagasi

\begin{abstract}
Interaction of auxin-cytokinin was important for regulation of growth and development in tissue culture. This research aimed to determine the suitable formula of plant growth regulators on callus filament regeneration of seaweed $K$. alvarezii. The callus filament was cultured on liquid media with PGR formulation of indole acetic acid (IAA): kinetin: zeatin, with formulation: A $(0,4: 0: 1) \mathrm{ppm}$; B $(0,4: 0,25: 0,75) \mathrm{ppm}$; C $(0,4: 0,5: 0,5) \mathrm{ppm} D$ $(0,4: 0,75: 0,25) \mathrm{ppm} ; \mathrm{E}(0,4: 1: 0) \mathrm{ppm}$; control (without PGR). Research was designed with completely randomized design with 3 replications of each treatment. Observed parameters were daily growth rate, survival rate, regeneration rate, length of shoots regenerated and morphology. The results showed that the best PGR formula was formula $A$ with daily growth rate of $1.929 \% /$ day, survival rate of $83.33 \%, 41.67 \%$ of regeneration rate and average length of shoots of $44.59 \mu \mathrm{m}$. The shoots began to regenerate in 15 days culture.
\end{abstract}

Key words: auxin, cytokines, plant growth regulators, K. alvarezii, micropropagation

\section{PENDAHULUAN}

Rumput laut $K$. alvarezii merupakan salah satu komoditas prioritas karena memiliki beberapa keunggulan. Keunggulannya yaitu teknologi budidayanya mudah dilakukan, modal yang diperlukan dalam budidaya rumput laut relatif kecil, usia panen singkat sehingga merupakan komoditas yang cepat untuk mengatasi kemiskinan

\footnotetext{
* Alamat korespondensi:

Sri Redjeki Hesti Mulyaningrum

Email: titut_suryanto@yahoo.com

Alamat : Fakultas Perikanan dan Kelautan, Universitas Brawijaya, Malang
}

serta kegiatan budidaya rumput laut hingga proses pengolahan pasca panen merupakan kegiatan yang padat karya. Sehingga rumput laut sering disebut komoditas yang memenuhi kriteria triple track : pro job, pro poor dan pro growth. Pada aspek budidaya mampu menjadi kunci pemberdayaan masyarakat pesisir, selain itu permintaan pasar dunia masih sangat tinggi [1].

Salah satu kendala dalam pengembangan budidaya rumput laut adalah keterbatasan benih yang kontinyu dan berkualitas. Apalagi untuk mendukung program strategi minapolitan dimana produksi perikanan sebesar 8 juta ton pada 2009 akan dipacu hingga 353\% pada 2014 sehingga 
ketersediaan benih rumput laut secara kontinyu dan berkualitas mutlak diperlukan.

Perkembangan mikropropagasi tanaman melalui teknik kultur organ, kultur jaringan dan kultur sel memberikan prospek yang menjanjikan bagi pengembangan bioteknologi tanaman, dan peluang yang besar pada manipulasi genetik, propagasi tanaman dan produksi tanaman komersil. Kesuksesan teknik-teknik mikropropagasi pada tumbuhan tingkat tinggi mendorong pengembangannya pada rumput laut yang secara umum bertujuan untuk meningkatan ekonomi dengan peningkatan produksi rumput laut. Kultur jaringan rumput laut dengan menggunakan teknik induksi kalus banyak digunakan untuk propagasi klon dan perbaikan mutu genetik untuk mendukung ketersediaan benih yang kontinyu dan berkualitas [2].

Pembelahan sel diatur oleh aksi bersama auksin dan sitokinin, masing-masing mempengaruhi fase berbeda dari siklus sel. Auksin mempengaruhi replikasi DNA, sedangkan sitokinin tampaknya mengerahkan beberapa kendali atas kejadian yang menyebabkan mitosis dan sitokinesis. Dengan demikian, tingkat auksin dan sitokinin dalam kultur perlu seimbang dan secara hati-hati dikendalikan [3].

\section{METODE PENELITIAN Inisiasi dan proliferasi}

Tujuan inisiasi dan proliferasi adalah untuk menyiapkan filamen kalus yang digunakan dalam penelitian. Induksi kalus dilakukan dengan metode Reddy et al. [4]. Sampel rumput laut dipotong dengan ukuran $2 \mathrm{~cm}$. Kemudian mencuci eksplan dengan air laut steril. Selanjutnya melakukan sterilisasi eksplan dengan mencuci eksplan dengan $0,1 \%$ larutan detergen cair dalam air laut steril selama 10 menit. Eksplan kemudian diperlakukan dalam larutan iodine (bethadine 0,1\%) dalam air laut steril selama 3 menit untuk menghilangkan mikroba. Sterilisasi eksplan dilanjutkan dengan $0,1 \%$ antibiotik mix spektrum luas kemudian dicuci air laut steril sampai 3 kali. Selanjutnya eksplan direndam pada larutan $0,1 \%$ antibiotik mix spektrum luas dalam media Conwy selama 2 hari.

Eksplan steril dikeringkan dengan tissue steril untuk mengurangi kelembaban, kemudian dipotong-potong sepanjang $4-5 \mathrm{~mm}$. Eksplan kemudian diinokulasi dalam cawan petri pada media agar 0,8\% dalam media Conwy dengan kepadatan 20 eksplan/cawan petri. Pemeliharaan dilakukan di lemari kultur dengan suhu $20^{\circ} \mathrm{C}$ dengan penerangan lampu neon 1500 lux dengan fotoperiod L : $D=12$ : 12 selama 60 hari atau hingga filamen kalus terbentuk. Inokulum disubkultur setiap 7 hari dengan media baru yang sama.

Perkembangan filamen kalus diamati denganmikroskop (Bausch \& Lomb). Gambaran kalus yang terbentuk dipotret dengan kamera digital (Optika Microscopes CCD Sensor).

\section{Formulasi auksin dan sitokinin}

Filamen kalus yang dihasilkan dikultur pada media cair Conwy yang diperkaya dengan ZPT auksin (IAA) dan sitokinin (kinetin dan zeatin) dengan formulasi sebagai berikut : $A(0,4: 0: 1)$ ppm; B $(0,4: 0,25: 0,75)$ ppm; C $(0,4: 0,5: 0,5)$ ppm; D $(0,4: 0,75: 0,25)$ ppm; E (0,4: $1: 0)$ ppm; kontrol (tanpa ZPT).

Kultur dilakukan selama 30 hari pada shaker dengan penerangan lampu neon berkekuatan 1500 lux, L : D 12 : 12 pada suhu $20^{\circ} \mathrm{C}$. Setiap 15 hari dilakukan penggantian media dan pengamatan perkembangan morfologi. Pada akhir kultur dilakukan pengukuran laju pertumbuhan harian, sintasan, kecepatan regenerasi dan panjang tunas. Laju pertumbuhan harian dihitung dengan menimbang filamen kalus dan dihitung menggunakan rumus berikut :

$$
\begin{aligned}
& \text { Growth Rate }\left(\% \text {. hari }{ }^{-1}\right)=100 \frac{\ln W t / W_{0}}{t} \\
& \text { dimana : } \\
& \text { GR } \quad=\text { Laju pertumbuhan harian } \\
& \mathrm{W}_{\mathrm{t}} \quad \text { = berat akhir filamen kalus } \\
& \mathrm{W}_{0} \quad \text { = berat awal filamenkalus } \\
& \mathrm{t} \quad=\text { lama kultur }
\end{aligned}
$$

Sintasan diperoleh dengan menghitung filamen yang hidup. Adapun rumus sintasan adalah sebagai berikut :

$$
\text { Survival Rate }(\%)=\left[\frac{N_{t}}{N_{0}}\right] 100 \%
$$

dimana :

SR = Survival rate (sintasan)

$\mathrm{Nt}=$ Jumlah filamen kalus yang hidup

$\mathrm{N}_{0}$ = Jumlah filamen kalus awal

Sedangkan laju regenerasi diukur dengan metode Yokoya et al. [5] dengan menghitung 
jumlah filamen kalus yang beregenerasi. Rumus laju regenerasi adalah sebagai berikut:

$$
\mathrm{R}(\%)=\left[\frac{F_{r}}{F_{0}}\right] 100 \%
$$

dimana :

$\mathrm{R} \quad=$ Laju regenerasi $(\%)$

$\mathrm{Fr} \quad=$ Jumlah filamen kalus yang beregenerasi

$F_{0} \quad$ Jumlah filamen kalus awal

Panjang tunas diukur secara mikroskopis dengan mikroskop Olympus 1 X71. Semua data yang diperoleh dianalisis dengan analisis ragam ANOVA, sedangkan data perkembangan morfologi disajikan secara deskriptif dari hasil pengamatan secara mikroskopis.

\section{HASIL DAN PEMBAHASAN}

\section{Inisiasi dan proliferasi}

Hasil inisiasi dan proliferasi memperlihatkan bahwa induksi kalus dimulai dengan pigmentasi pada permukaan eksplan (kortikal) kemudian terbentuk kalus pada bagian tengah (medular) dan lapisan kortikal. Kalus berwarna coklat tua, dan terdiri dari filamen yang berasal dari pembelahan sel yang dihasilkan sebagai respon dari luka di permukaan irisan.

Filamen kalus mulai terbentuk pada umur pemeliharaan 21 hari. Hasil ini sama dengan penelitian Munõz et al. [6] dan Hayashi et al. [7] yang mendapati terbentuknya kalus $K$. alvarezii masing-masing setelah 16 hari dan 15 hari masa pemeliharaan. Waktu induksi ini lebih singkat dari waktu induksi rumput laut jenis Halymenia sinensis yang memerlukan waktu 50 hari untuk membentuk kalus [8]. Filamen berkembang pada sel medular rumput laut, pada bagian tengah sel medular terjadi pigmentasi yang merupakan bagian dari filamen kalus (Gambar 1).

Filamen kalus yang terbentuk berupa filamen berbentuk kristal dan filamen kalus berpigmen. Menurut Munõz et al. [6], eksplan K. alvarezii memproduksi filamen kalus berbentuk kristal dan filamen kalus berpigmen. Sedangkan menurut Kumar et al. [9] pada Turbinaria conoides didapati filamen kalus dalam dua bentuk: (a) filamen kalus berserabut yang terbentuk pada pusat potongan eksplan, (b) filamen kalus yang berbentuk gelembung-gelembung. Sel filamen kalus yang dihasilkan dalam penelitian ini berbentuk bulat (Gambar 2). Pada dasarnya bentuk sel filamen kalus rumput laut ada dua macam, yaitu filamen kalus filiform dengan bentuk memanjang dan filamen kalus moniliform yang berbentuk bulat [9].
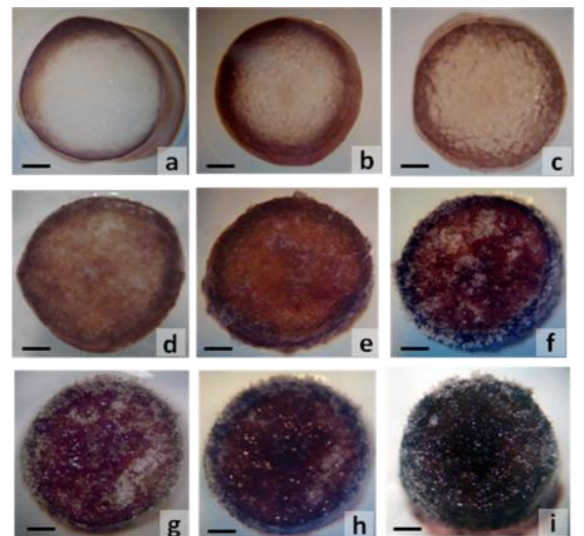

Gambar 1. Perkembangan kalus selama 60 hari pemeliharaan

skala bar $=10 \mu \mathrm{m}$; (a) awal inokulasi; (b) minggu ke-1; (c) minggu ke-2; (d) minggu ke-3; (e) minggu ke-4; (f) minggu ke-5; (g) minggu ke-6; (h) minggu ke-7; (i) minggu ke-8.

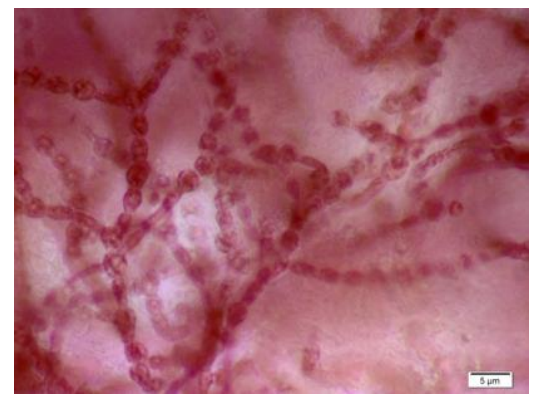

Gambar 2. Sel filamen kalus moniliform K. alvarezii (skala bar $=5 \mu \mathrm{m}$ )

Filamen kalus yang embriogenik berwarna coklat tua karena mengalami pigmentasi, sedangkan filamen kalus yang tidak embriogenik berwarna pucat dan berakhir dengan kematian (Gambar 3).
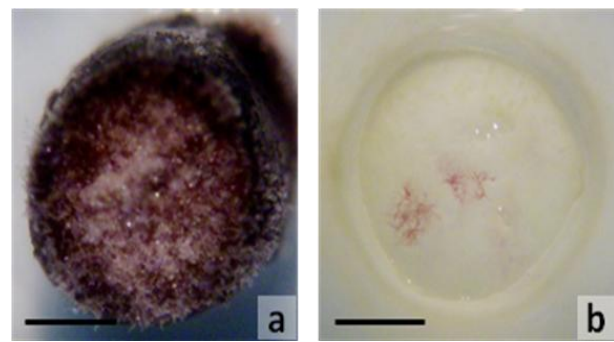

Gambar 3. Filamen kalus rumput laut $K$. alvarezii : embriogenik (a) dan yang tidak embriogenik (b) (skala bar $=20 \mu \mathrm{m}$ ) 
Menurut Rorrer dan Cheney [10] pembentukan kalus dimulai dengan pigmentasi pada daerah permukaan eksplan (kortikal) kemudian terbentuk filamen yang tidak terdiferensiasi pada eksplan dan berkembang menjadi tunas. Penambahan zat pengatur tumbuh IAA dapat menstimulasi pembentukan kalus yang akan membentuk filamen. Hal ini dapat dijelaskan karena zat pengatur tumbuh golongan auksin berperan dalam inisiasi pembelahan sel, dan organisasi dari meristem menjadi suatu jaringan tidak terorganisir - kalus $[5,11]$.

\section{Formulasi auksin dan sitokinin}

Laju pertumbuhan harian

Hasil pengamatan pertambahan bobot kalus rumput laut selama 30 hari pemeliharaan bervariasi dan semakin meningkat seiring dengan meningkatnya waktu pemeliharaan untuk semua perlakuan. Tampak bahwa pertambahan bobot tertinggi diperoleh pada perlakuan formula $A$ sebesar $0,0347 \mathrm{~g}$, kemudian disusul perlakuan $\mathrm{E}$ sebesar $0,0254 \mathrm{~g}$, selanjutnya formula $\mathrm{D}, \mathrm{C}$, dan B masing-masing sebesar 0,0151 g, 0,0117, 0,0096 g, dan terendah dalam penelitian ini pada kontrol tanpa pemberian zat pengatur tumbuh yakni 0,0064 g (Tabel 1).

Kisaran laju pertumbuhan harian adalah 0,440 1,929\%/hari (Gambar 4). Nilai ini lebih rendah dari hasil penelitian Huang et al. [12] yang memperoleh laju pertumbuhan harian mikroplantlet Agardhiella subulata pada kisaran $2-3 \% /$ hari.

Tabel 1. Rerata pertambahan bobot filamen kalus selama 30 hari pada setiap formulasi ZPT pemeliharaan

\begin{tabular}{cccc}
\hline $\begin{array}{c}\text { Formula } \\
\text { ZPT }\end{array}$ & Berat awal & Berat akhir & Berat mutlak \\
\hline A & $0,0466 \pm 0,0127$ & $0,0813 \pm 0,0074$ & $0,0347 \pm 0,0087$ \\
B & $0,0408 \pm 0,0068$ & $0,0504 \pm 0,0061$ & $0,0096 \pm 0,0018$ \\
C & $0,0545 \pm 0,0087$ & $0,0662 \pm 0,0042$ & $0,0117 \pm 0,0088$ \\
D & $0,0488 \pm 0,0142$ & $0,0639 \pm 0,00164$ & $0,0151 \pm 0,0044$ \\
E & $0,0432 \pm 0,0055$ & $0,0686 \pm 0,0043$ & $0,0254 \pm 0,0030$ \\
& & & \\
Kontrol & $0,0442 \pm 0,0097$ & $0,0506 \pm 0,0117$ & $0,0064 \pm 0,0020$
\end{tabular}

J. Exp. Life Sci. Vol. 2 No. 1, 2012

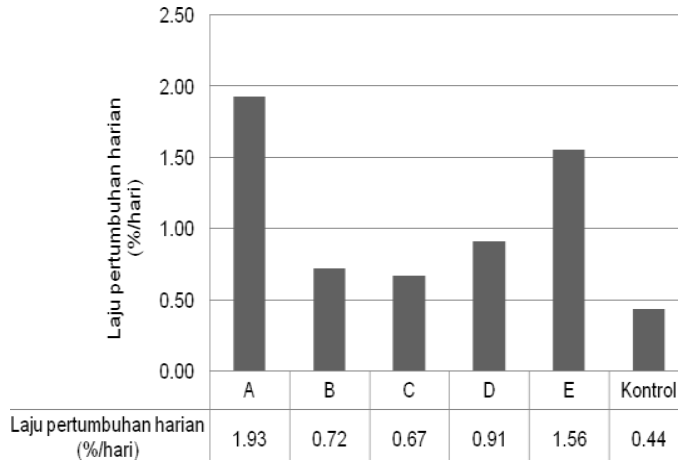

Gambar 4. Laju pertumbuhan harian filamen kalus pada berbagai formula ZPT

\section{Sintasan}

Uji keragaman (ANOVA) memperlihatkan bahwa penambahan zat pengatur tumbuh tidak memiliki efek yang signifikan terhadap sintasan $(P>0,05)$ filamen kalus. Sintasan tertinggi pada formula A $(83,33 \%)$ kemudian disusul formula $E$ dengan sintasan sebesar (75\%) sedangkan formula $B, C$ dan $D$ memiliki sintasan yang sama dengan kontrol $(66,67 \%)$ (Gambar 5).

Kematian mulai terjadi pada minggu pertama kultur. Menurut Huang et al. [12], kematian dapat diakibatkan oleh kondisi filamen yang yang stres akibat pemindahan dari media padat ke media cair. Selain itu kematian juga bisa diakibatkan karena adanya guncangan shaker yang terus menerus selama kultur.

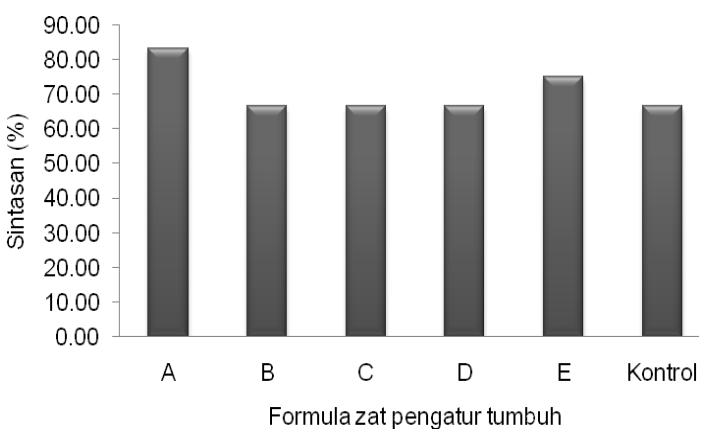

Gambar 5. Sintasan filamen kalus selama 30 hari pemeliharaan

\section{Laju regenerasi}

Laju regenerasi tertinggi dihasilkan pada formula A. Besarnya laju regenerasi untuk masingmasing formula adalah sebagai berikut : A 
$(41,67 \%) ; C(33,33 \%) ; E(33,33 \%) ; B(25 \%) ; D(25 \%)$ sedangkan kontrol tidak mengalami regenerasi (0\%). Antara perlakuan A, B, C, D dan E tidak berbeda nyata namun semua perlakuan berbeda nyata dengan kontrol (Tabel 2).

Kisaran persentasi regenerasi filamen yang dihasilkan pada penelitian ini hampir sama dengan penelitian Mussio and Russig [13] yang memperoleh persentasi regenerasi filamen Laminaria digitata pada kisaran 2,5-50\% dengan penambahan zat pengatur tumbuh 2,4Dichlorophenoxyacetic acid (2,4-D).

Hal ini memperlihatkan bahwa kombinasi zat pengatur tumbuh golongan auksin dan sitokinin dapat menstimulasi proses regenerasi filamen kalus rumput laut K.alvarezii. Terlihat bahwa golongan sitokinin jenis zeatin memiliki efek stimulasi lebih baik dibandingkan kinetin. Bradley and Cheney [14] berpendapat bahwa kombinasi auksin dengan zeatin memiliki efek regenerasi yang lebih tinggi dibandingkan kombinasi auksin dan kinetin. Perbedaan ini sangat dipengaruhi karakter dari zat pengatur tumbuh.

Tabel 2. Laju regenerasi filamen kalus rumput laut $K$. alvarezii pada berbagai formula ZPT

\begin{tabular}{cc}
\hline Formula ZPT & Laju regenerasi (\%) \\
\hline A & $41,67 a$ \\
B & $25,00 a$ \\
C & $33,33 a$ \\
D & $25,00 a$ \\
E & $33,33 a$ \\
Kontrol & $0 b$ \\
\hline
\end{tabular}

Keterangan: Nilai dalam baris yang sama diikuti oleh huruf yang sama menunjukkan berbeda tidak nyata $(P>0,05)$.

\section{Panjang tunas}

Semua perlakuan formula zat pengatur tumbuh memiliki panjang tunas yang berbeda nyata dengan kontrol. Panjang tunas tertinggi diperoleh pada formula A $(44,59 \pm 4,68 \mu \mathrm{m})$ yang berbeda nyata dengan formula $E(30,50 \pm 4,44 \mu \mathrm{m})$; $C(17,33 \pm$ $5,01 \mu \mathrm{m}) ; \mathrm{D}(15,67 \pm 6,03 \mu \mathrm{m}) ; \mathrm{B}(14,33 \pm 6,66$ $\mu \mathrm{m})$, dan kontrol (0). Formula $E$ berbeda nyata dengan formula B, C, D dan kontrol. Sedangkan formula B, C dan D masing-masing tidak berbeda nyata (Gambar 6).

Dari hasil analisis keragaman (ANOVA) menunjukkan bahwa penggunaan formulasi zat pengatur tumbuh yang berbeda berpengaruh nyata antar perlakuan $(P<0,05)$. Hasil penelitian ini sesuai dengan pendapat Yokoya dan Handro [15] yang menyatakan bahwa zat pengatur tumbuh dapat mengontrol pertumbuhan, proses morfogenesis dan mikropropagasi alga merah.

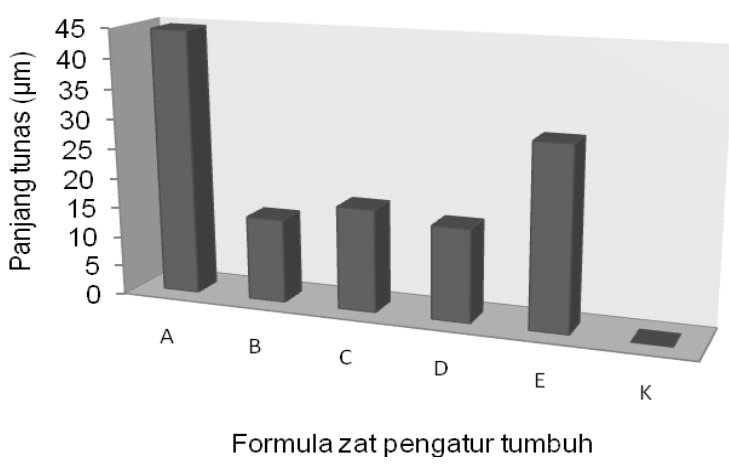

Gambar 6. Panjang rata-rata tunas rumput laut $K$. alvarezii pada berbagai formula ZPT

\section{Perkembangan morfologi}

Semua formula zat pengatur tumbuh kombinasi auksin dan sitokinin dalam penelitian ini memberikan efek regenerasi dan berpengaruh terhadap pertumbuhan rumput laut. Hal ini berbeda dengan kontrol yang tidak mengalami regenerasi. Konsentrasi sitokinin yang lebih tinggi daripada auksin dapat menstimulasi pembelahan sel dengan meningkatkan sintesis protein dan aktivitas metabolisme yang meningkatkan proses diferensiasi sel. Kombinasi auksin dan sitokinin mampu menstimulasi regenerasi filamen rumput laut menjadi tunas pada media cair serta memiliki peran regulasi dalam pertumbuhan dan morfogenesis $[4,5,15]$.

Berdasarkan suatu hipotesis yang disebut hipotesis pertumbuhan asam (acid growth hypothesis), golongan auksin berperan dalam pembesaran sel. Zat pengatur tumbuh golongan auksin dapat memicu pompa proton untuk meningkatkan jumlah $\mathrm{H}^{+}$ke dalam sel sehingga sitoplasma sel menjadi lebih asam kemudian menyebabkan melonggarnya ikatan polisakarida pada dinding sel. Dengan demikian air dengan mudah berosmosis ke dalam sel dan menyebabkan sel mengalami pembesaran. Pembentukan tunas ditandai dengan memadatnya filamen dan kemudian beregenerasi membentuk tunas. Hal ini bisa teramati secara mikroskopis, filamen kalus yang memadat akan membentuk tunas. Sedangkan 
pada kontrol tidak terjadi pemadatan filamen kalus sehingga tidak terbentuk tunas (Gambar 7) $[3,12]$.

Tunas mulai terbentuk pada umur pemeliharaan 15 hari. Menurut Gaspar et al. [11] interaksi auksin-sitokinin dianggap penting untuk mengatur pertumbuhan dan perkembangan dalam jaringan tanaman dan kultur organ, karena kedua kelas hormon tersebut umumnya diperlukan oleh tumbuhan. Auksin dan sitokinin eksogen yang ditambahkan akan berinteraksi dengan hormon endogen tanaman. Selain itu, jaringan yang tidak responsif akan menanggapi aplikasi hormon eksogen tersebut. Auksin memiliki pengaruh yang kuat pada proses-proses seperti ekspansi pertumbuhan sel, pengasaman dinding sel, dan mempercepat diferensiasi vaskular. Banyak aspek pertumbuhan sel, diferensiasi sel, dan organogenesis dalam kultur jaringan dan organ tubuh ditemukan dikontrol oleh interaksi antara sitokinin dan auksin. Konsentrasi setiap zat pengatur tumbuh sangat bervariasi sesuai dengan jenis tanaman yang dikultur, kondisi kultur, dan bentuk zat pengatur tumbuh yang digunakan. Kombinasi auksin dan sitokinin memiliki efek stimulasi pada pembentukan kalus, pertumbuhan dan regenerasi [2].

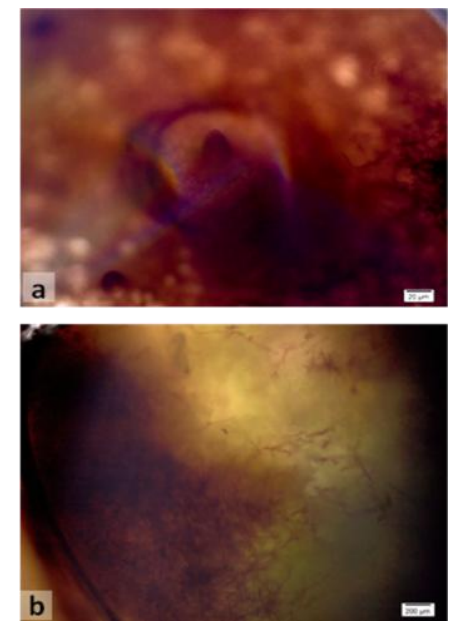

Gambar 7. Morfologi tunas rumput laut $K$. alvarezii : (a) Filamen kalus yang membentuk tunas (tanda panah); (b) filamen kalus yang tidak membentuk tunas.

\section{KESIMPULAN DAN SARAN}

Perbandingan zat pengatur tumbuh auksin dan sitokinin yang tepat dapat meningkatkan morfogenesis filamen kalus rumput laut $K$. alvarezii. Komposisi auksin dan sitokinin yang optimum bagi regenerasi filamen kalus rumput laut
K.alvarezii adalah IAA: zeatin dengan perbandingan 0,4 : 1. Perlu dilakukan kombinasi formula ZPT optimum dengan beberapa media kultur untuk meningkatkan laju regenerasi.

\section{UCAPAN TERIMA KASIH}

Terima kasih yang sebesar-besarnya disampaikan kepada Ibu Dra. Emma Suryati, MSi dan saudari Siti Fadilla, S.Si. atas bantuannya selama pelaksanaan penelitian.

\section{DAFTAR PUSTAKA}

[1] Anggadiredja. 2007. Rumput Laut. Penebar Swadaya. Jakarta. 50-53.

[2] Reddy C.R.K., Jha B. and Fujita Y. 2008. Seaweed micropropagation techniques and their potentials : an overview. J. Appl. Phycol., 20: 609-617.

[3] Dewi I.R. 2008. Peranan dan fungsi fitohormon bagi pertumbuhan tanaman. Fakultas Pertanian Universitas Padjadjaran Bandung. 36 hal.

[4] Reddy C.R.K., R.K. Kumar, Siddhanta A.K. and Tewari A. 2003. In vitro somatic embryogenesis and regeneration of somatic embryos from pigmented callus of Kappaphycus alvarezii (Doty) Doty (Rhodophyta, Gigarti-nales). J. Phycol., 39: 610-616.

[5] Yokoya N.S., West J.A. and Luchi A.E. 2004. Effects of plant growth regulators on callus formation, growth and regeneration in axenic tissue cultures of Gracilaria tenuistipitata and Gracilaria perplexa (Gracilariales, Rhodophyta). Phycol. Res., 52: 244-254.

[6] Munõz J., Lõpez A.C.C., Patiño R. and Robledo D. 2006. Use of plant plant growth regulators in micropropagation of kappaphycus alvarezii (Doty) in airlift bioreactors. J. Appl. Phycol., 18: 209-218.

[7] Hayashi L., Yokoya N.S., Kikuchi D.M. and Oliveira E.C. 2008. Callus Induction and Micropropagation Improved By Colchicine and Phytoregulators in Kappaphycus alvarezii (Rhodophyta, Solieriaceae). J. Appl. Phycol., 20: $653-659$.

[8] Wang A., Li S. and Duan D. 2006. Filament induction in Halymenia sinensis (Halymeniaceae, Rhodophyta). Bot. Marina, 49: $352-354$. 
[9] Kumar G.R., Reddy C.R.K. and Jha B. 2007. Callus induction and thallus regeneration from callus of phycocolloid yielding seaweeds from the Indian coast. J. Appl. Phycol., 19: 15 -25 .

[10] Rorrer G.L. and Cheney D.P. 2004. Bioprocess engineering of cell and tissue cultures for marine seaweeds. Aquacultural Engineering, 32: 11-41

[11] Gaspar T., Kevers C., Penel C., Greppin H., Reid D.M. and Thorpe T.A. 1996. Plant Hormones and Plant Growth Regulators In Plant Tissue Culture. In Vitro Cell Dev. Biol. Plant, 32: $272-289$.

[12] Huang Y., Maliakal S., Cheney D.P. and Rorrer G.L. 1998. Comparison of development and photosynthetic growth for filament clump and regenerated microplantlet culture of Agardhiella subulata (Rhodophyta, Gigartinales). J. Phycol., 34: 893 - 901.

[13] Mussio I. and Rusig A.M. 2009. Morphogenetic responses from protoplasts and tissue culture of Laminaria digitata (Linnaeus) J. V. Lamouroux (Laminariales, Phaeophyta): callus and thalloid-like structures regeneration. J. Appl. Phycol., 21: 255-264.

[14] Bradley P.M. and Cheney D.P. 1990. Some effects of plant growth regulators on tissue cultures of the marine red alga Agardhiella subulata (Gigartinales, Rhodophyta). Hydrobiologia, 204/205: 353-360.

[15] Yokoya N.S and Handro W. 1996. Effect of auxins and cytokinins on tissue culture of Grateloupia dichotoma (Gigartinales, Rhodophyta). Hydrobiologia, 326/327: 393 400. 